Article

\title{
Future Skills of Flight Attendants in Times of COVID-19-Related Job Uncertainty-The Case of Germany
}

\author{
Kirsten Friederike Bremer ${ }^{1}$ and Sven Ulrich Maertens ${ }^{2, *(D)}$ \\ 1 Distance Learning Business and Management, IU International University of Applied Sciences, \\ 99084 Erfurt, Germany; kirsten.bremer@gmx.de \\ 2 Institute of Air Transport and Airport Research, German Aerospace Center (DLR e.V.), \\ 51147 Cologne, Germany \\ * Correspondence: sven.maertens@dlr.de
}

Citation: Bremer, Kirsten Friederike, and Sven Ulrich Maertens. 2021. Future Skills of Flight Attendants in Times of COVID-19-Related Job Uncertainty-The Case of Germany. Administrative Sciences 11: 154 https://doi.org/10.3390/admsci 11040154

Received: 6 October 2021

Accepted: 10 December 2021

Published: 17 December 202

Publisher's Note: MDPI stays neutral with regard to jurisdictional claims in published maps and institutional affiliations.

Copyright: (c) 2021 by the authors. Licensee MDPI, Basel, Switzerland. This article is an open access article distributed under the terms and conditions of the Creative Commons Attribution (CC BY) license (https:/ / creativecommons.org/licenses/by/ $4.0 /)$.

\begin{abstract}
Future skills" increase employees' prospects in the labor market, particularly in dynamic times, such as the current COVID-19 pandemic. (Not only) in Germany, flight attendants represent an occupational group without state-recognized vocational occupation who are particularly affected by the pandemic due to serious and long-lasting declines in air transport volumes. Therefore, it is reasonable to assume that the future skills of flight attendants play an important role when applying for jobs in other industries. An empirical survey $(n=273)$ from April 2021 indicates that Germanspeaking flight attendants possess some of the future skills most frequently identified in key studies on future competencies, as well as extensive language skills, but have deficits in "working with computer systems" and "programming". Pro-active training of employees in future skills, especially in crisis-prone professions, could facilitate future transitions into new professional fields.
\end{abstract}

Keywords: air transport; flight attendants; future skills; future competencies; COVID-19; further education; training; employee

\section{Introduction}

The air transport industry has been and still is, severely affected by the COVID-19 pandemic, with global air traffic in, e.g., Germany, plummeting by over 74 percent in 2020 (Statistisches Bundesamt 2021). Since spring 2020, airline staff have largely been on short-time work or have already been laid off (Keller 2021). The situation is not very different in the rest of the world, and, despite a recent turnaround, it is still not foreseeable when passenger air traffic will eventually return to pre-crisis levels. According to the IATA (International Air Transport Association) Airline Business Confidence Index from October 2021, published on 10 November 2021, only $47 \%$ of top airline executives surveyed expect an improvement in employment levels within the next 12 months, despite widely $(88 \%)$ expected demand recovery (IATA (International Air Transport Association) 2021).

The need for job changes has, therefore, become a reality for many flight attendants, especially as the number of planned, or already implemented, job cuts at major airlines, such as United Airlines, American Airlines, Air France or Lufthansa, is reported to run into the thousands (Koenen 2020).

Switching to a new job can be challenging for flight attendants in Germany-and probably elsewhere-as the profession "flight attendant" is not a state-recognized vocational occupation. This can make it particularly difficult for them to change, e.g., into the rigid structures of the public sector, where formal professional qualifications are usually decisive for recruitment, job classification and thus salary levels.

Generally, many workplaces, production processes and, therefore, also the demands of employees have changed significantly. The modern working world can be characterized by "increasing digitization, globalization and individualization" (Bruckner et al. 2018). Individual work steps up to entire workplaces and sectors have already been rationalized 
by increasing digitization, automation and globalization, while other, often more complex activities and processes have been emerging. Therefore, a professional reorientation has become or may threaten to become, a necessity for many people, regardless of the pandemic.

In recent studies, various "transformation competencies" and "skills" (OECD 2019), such as "critical thinking, problem solving, communication, and collaboration" (Partnership for 21st Century Learning (P21) (Partnership for 21st Century Learning (P21)) 2019, p. 2) are classified as significant in order to be successful (OECD 2019) and effective (Partnership for 21st Century Learning (P21) (Partnership for 21st Century Learning (P21)) 2019) and thus "employable" in the world of work 4.0. The term "employability" describes the ability to actively participate in working and professional life (Sauter et al. 2018, p. 253).

McKinsey and the "Stifterverband für die Deutsche Wissenschaft" (a German donors' association for the promotion of science) use the term "future skills" to describe such competencies that are likely to become significantly more important for working life and/or social participation in the next years-across all sectors and industries (Kirchherr et al. 2018, p. 4).

As it can be assumed that future skills can decisively help flight attendants to find a new job, this paper examines existing, and possibly missing, future competencies of flight attendants. More precisely, we compare the actual future competencies of flight attendants in Germany-determined by an online survey of $n=273$ German-speaking cabin crew members and from the airlines' job requirement profiles-with the most important future skills according to current studies in this field. Hereby, we use the terms future skills and future competencies synonymously.

The paper is structured as follows: Section 2 first reviews the existing literature on future competencies and-with a special focus on human resource management issues-on flight attendants, and then demonstrates the research gap. Section 3 presents the paper's methodologic approaches; (a) to identify the most relevant future competencies from selected literature sources and to empirically reveal the (b) assumed and (c) actual future competencies of German-speaking flight attendants. Section 4 presents the results and identifies competence overlaps and gaps. Section 5 discusses the results, and Section 6 concludes by deriving recommendations and discussing limitations.

\section{Background/Literature}

\subsection{Work 4.0 and (Future) Competencies}

"Work 4.0" (German: Arbeit 4.0) is a collective term mainly used in Germany (e.g., Federal Ministry of Labour and Social Affairs of Germany 2017). It refers to the future of work in times of globalization, digitalization, individualization and demographic change (Bruckner et al. 2018). This includes both changing forms of work and working conditions, as well as increasing demand for digital media and IT in general. The world has been moving closer together for years through globalization and the Internet, enabling international connections and business relationships across the world-a process which was further accelerated and made more flexible through digitalization (Fischer et al. 2018, p. 88).

Individualization primarily refers to changes in the form of work and working conditions, as they are often implemented in start-ups where flexible working time arrangements, home office solutions and employee participation models are implemented as means to increase motivation and identification (Schubert 2018, p. VI). According to Jacobs et al. the society as a whole should understand the design of Work 4.0 as a mission (Jacobs et al. 2018, p. 28) - not least because demographics are leading to increased retirement. Employees are getting older and older, while the supply of the young workforce with similar know-how is often limited (Anger et al. 2020, p. 19).

It is not straightforward to find a consistent definition of "competence" (Seitz and Seitz 2018, p. 356). Competence is often used as an umbrella term that encompasses skills, knowledge and motivation, but above all, enables a person to act responsibly and independently in complex, evolving, uncertain and/or unknown situations (e.g., Cattaneo et al. 2022; Bundesinstitut für Berufsbildung 2015). In the context of human 
resources, competence (or: competency) generally refers to knowledge, personal, social and/or methodological abilities and skills needed to perform successfully on the job (e.g., European Commission 2008).

In the more recent literature, a number of terms are used to describe competencies that are becoming - or are supposed to become-increasingly relevant in the future world of work: Examples are "21st century skills" (Partnership for 21st Century Learning (P21) (Partnership for 21st Century Learning (P21)) 2019, p. 8), "future skills" (Kirchherr et al. 2020), "Schlüsselkompetenz" (a German term best translated as "key competence") (Robertson-von Trotha et al. 2009, p. 144) or "future competence" (Bruns 2018, p. 267; Koch 2017, p. 42; Lüneburg 2020, p. 1). In this paper, we use both the terms "future skills" and "future competencies" because these terms are both used in the literature and are likely to allow for an intuitive understanding.

Future skills and competencies shall help to boost the implementation of Work 4.0 and to support the constant change to which both employees and the entire world of work are exposed. The new jobs created in the course of automation, globalization and digitalization tend to be more demanding than many of the former jobs, which increases the demands on employee qualification (Bonin et al. 2015, p. ii).

The literature body contains some papers on future skills and competencies required in specific (service) industries, from a case study on academic reference librarians in New Zealand (Chawner and Oliver 2013) to the maritime industry (Cicek et al. 2019) and the US low wage service sectors (Gatta et al. 2009). Among the identified future skills in all papers are communication skills, flexibility and technical or software skills. A review of papers on skills and competencies required in the hospitality industry, albeit neither explicitly related to future competencies nor to the airline industry, is provided by Kim and Park (2014). Generic competencies that were mentioned as important in these papers include social, leadership and organizational skills (Grau-Gumbau et al. 2002) and communication and other managerial skills (e.g., Agut et al. 2003).

\section{2. (Competencies of) Flight Attendants}

As cabin crew on board a commercial aircraft, the central tasks of flight attendants are the safety and care of passengers (Bentner 1998, p. 123). They can be seen as key factors and differentiators in passenger service delivery and satisfaction (Babbar and Koufteros 2008; Karatepe and Eslamlou 2017), not least because they are the only airline employees who have, as "frontline service employees" (Gibbs et al. 2017), almost continuous customer contact during the air passenger journey. Flight attendants are usually trained by their employer, the airline, according to regulatory requirements and industry-wide and airline-specific standards, both in passenger service and for a variety of irregularities and emergencies. In Europe, Commission Regulation (EU) No. 965/2012 (Annex III, Organisation Requirements for Air Operations, Subpart CC) contains provisions on cabin crew training courses and associated checking.

Academic literature on flight attendants (see Table 1) addresses a number of different issues, such as their contribution to airline service quality, performance and customer satisfaction (e.g., Kockelke 2008; Karatepe and Vatankhah 2014; Choi et al. 2020), their role in airline safety (e.g., Ford et al. 2013; Kao et al. 2009; Ji et al. 2019; Vatankhah 2021) or approaches to airline crew scheduling (e.g., Wen et al. 2021), which can also consider individual e.g., language) skills of flight attendants (Doerner et al. 2002). 
Table 1. Selected literature on flight attendants.

\begin{tabular}{|c|c|}
\hline Issue/Focus & Exemplary Papers \\
\hline Role and (perceived) image of flight attendants & $\begin{array}{l}\text { Bentner (1998), Tyler and Abbott (1998), Latson } \\
\text { (2015) }\end{array}$ \\
\hline Cabin crew scheduling and rostering & Doerner et al. (2002), Wen et al. (2021) \\
\hline $\begin{array}{c}\text { Impact of cabin crew behavior and } \\
\text { performance on safety and customer service } \\
\text { (quality) }\end{array}$ & $\begin{array}{l}\text { Babbar and Koufteros (2008), Kockelke (2008), } \\
\text { Bani-Salameh et al. (2011), Kao et al. (2009), } \\
\text { Vieira and dos Santos (2010), Ford et al. (2013), } \\
\text { Karatepe and Vatankhah (2014), Gibbs et al. } \\
\text { (2017), Karatepe and Eslamlou (2017), Ji et al. } \\
\text { (2019), Choi et al. (2020), Vatankhah (2021) }\end{array}$ \\
\hline Job satisfaction and mental health & $\begin{array}{l}\text { Cheng et al. (2018), Tang et al. (2020), } \\
\text { Lee et al. (2012), Park and Park (2019) }\end{array}$ \\
\hline Flight attendant's competencies & $\begin{array}{l}\text { Lu and Ling (2008), Vieira and dos Santos } \\
\text { (2010), Limprasert and Witthawassamrankul } \\
\text { (2016), Gibbs et al. (2017), Kusumo (2016) }\end{array}$ \\
\hline
\end{tabular}

In the field of human resources (management), in a narrower sense, published work on cabin crew members tackles issues, such as job satisfaction and mental health (e.g., Tang et al. 2020; Cheng et al. 2018; Lee et al. 2012), or the way and direction airlines "make up" and shape their female cabin crew members (Tyler and Abbott 1998).

There is a limited range of papers that deal explicitly with the competencies and skills of flight attendants. Lu and Ling (2008) empirically assessed drivers of customer satisfaction and service quality in Chinese cross-strait air transport; they found that Taiwanese travelers judged the capacity of Taiwanese airlines' flight attendants to communicate and respond lower than Mainland China travelers evaluating airlines from Mainland China.

Two papers from 2016 dealt with speaking skills: Limprasert and Witthawassamrankul (2016) identified accents and pronunciation as key English language issues of Thai flight attendants; and Kusumo (2016) revealed typical communication problems of cabin crew members in real-life working conditions and investigated how problem-based learning techniques could help to develop Indonesian flight attendants' speaking skills.

An example of a study linking flight attendant competencies to safety issues is a paper by Vieira and dos Santos (2010), who employed documental research to stress the importance of communication skills to avoid tensions in flight operations that could positively impact the risk of fatal accidents.

Papers dealing with cabin crew competencies from the training perspective include Gibbs et al. (2017) and Kim and Park (2014) — both in the form of a regional case study. Gibbs et al. (2017) empirically assessed the effects of competency-based training (CBT) in the areas "managing stress", "dealing with conflicts", "displaying human relations skills" and "delivering quality customer service" on flight attendants' performance and passenger satisfaction. A group of 109 flight attendants employed on routes between the Caribbean and North America received special training in these areas. As a result, the mean customer satisfaction score was significantly higher post-CBT compared to pre-CBT.

Kim and Park (2014) identified ways to develop competence-related training programs for airline cabin crews in Korea. They argued that competence-based training is an essential addition to the learning of specific job skills and applied a survey methodology to identify important competencies airline cabin crew members of a leading Korean airline should have. Overall, the respondents rated "customer-oriented skills and company loyalty", "appearance and attitude", "interpersonal skills", "emotional intelligence" and "knowledge of foreign cultures and languages" as competencies of above-average importance.

However, all these papers focus on the competencies required for the (current) job as a flight attendant, while, to our best knowledge, there is a gap in the (journal) literature with regard to the actual (future) competencies flight attendants may require when switching 
to other sectors. Hence, this paper may constitute a valuable contribution to the existing literature.

\section{Methodology}

Our approach can be summarized as in Figure 1. We first screen relevant sources to derive the most important future competencies. In the second step, we assess the actual skills of flight attendants, determined through an analysis of airline job profiles on the one hand and by descriptive statistics stemming from an online survey of $n=273$ German-speaking flight attendants on the other hand.

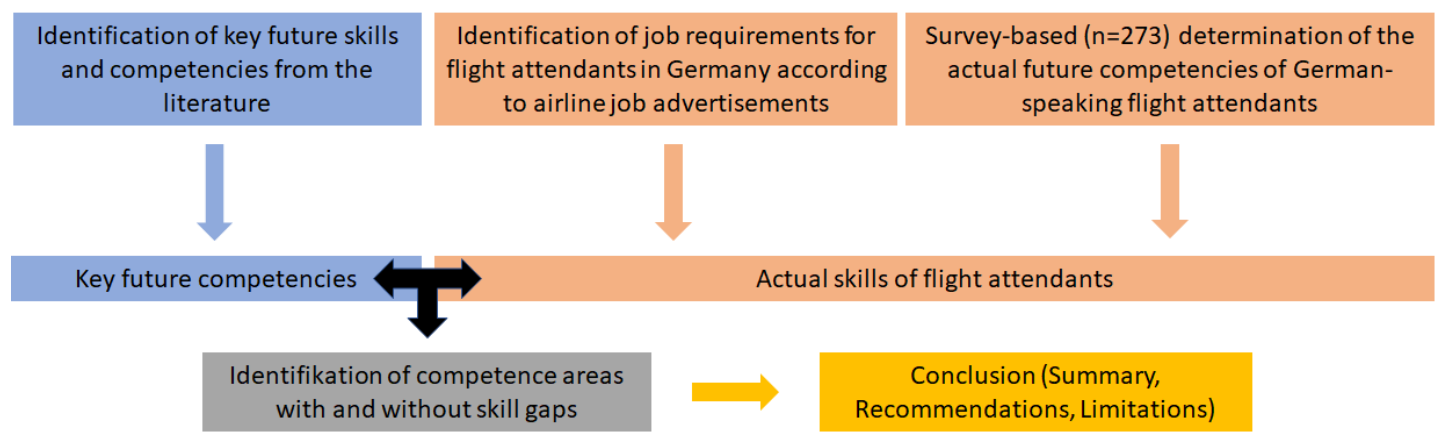

Figure 1. Approach.

We then compare and discuss the future competencies according to the literature with the actually observed skills of flight attendants from Germany to identify skill gaps and to generate a basis for recommendations for action. In the following, each step is described in more detail.

\subsection{Identification of Key Future Skills from the Literature}

We compared ten studies (see Figure 2) on future competencies from different countries, using the so-called ESCO classification as a reference (ESCO 2020b). ESCO stands for "European Skills/Competencies, qualifications and Occupations", a project of the European Commission in which a multilingual European classification scheme for skills, competencies, qualifications and occupations was developed (ESCO 2020a).

The studies were identified in searching academic literature databases, such as scholar.google.de, sciencedirect.com or the German database, hbz-nrw.de, for the recent literature on "future skills" and "future competencies" (as well as the German translation "Zukunftskompetenzen"), and some of them occurred repeatedly during the literature research and were cited frequently.

Consequently, while they are strictly speaking of just a convenience sample, it is reasonable to regard these ten sources as important examples of the current literature body on future skills.

To illustrate the methodology, Figure 2 presents an excerpt of the literature analysis and shows the most important future competencies from the overarching literature comparison according to the number of mentions of associated single competencies from the specific ESCO skill and competence areas. This way, a total of 43 different future competencies could be identified (column 3) and assigned to 24 specific ESCO skills and competencies (column 2). The results are described in Section 4.1. 


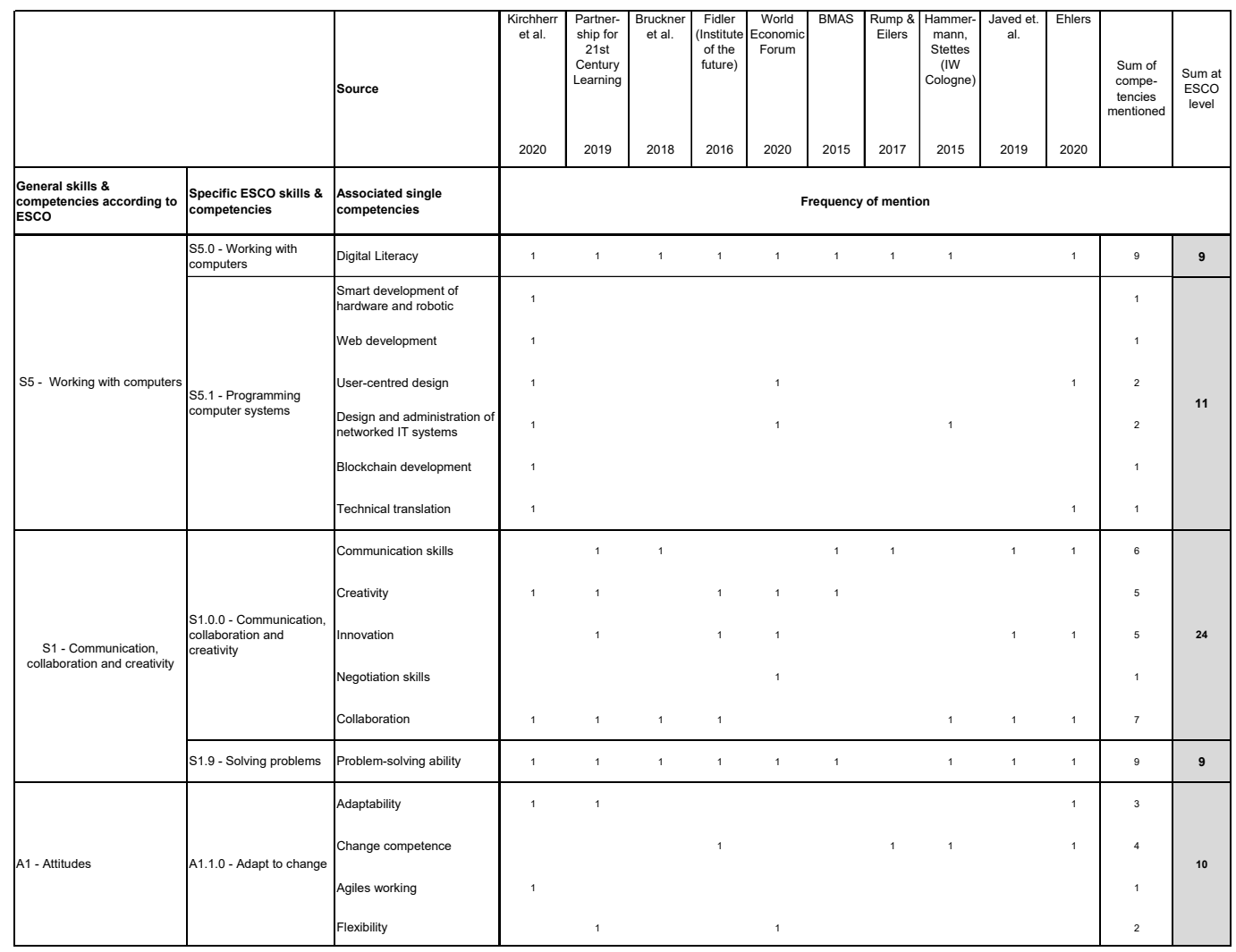

Figure 2. Approach to identify key future competencies from ten literature sources (ESCO classification) (Microsoft Excel screenshot for illustration). (BMAS-Bundesministerium für Arbeit und Soziales 2015; World Economic Forum 2020; Javed et al. 2019; Hammermann and Stettes 2015; Ehlers 2020; Fidler 2016).

3.2. Identification of Job Requirements for Flight Attendants in Germany According to Airline Job Advertisements

To identify the actual qualifications that airlines demand from flight attendants, we compared job profiles published in Germany by seven different airlines: Condor, EasyJet, Eurowings, Eurowings Discover, Lufthansa, Lufthansa CityLine and TUIfly. The job requirements of Lufthansa CityLine, Eurowings, Lufthansa, TUIfly and EasyJet were taken from an information sheet published by the German Federal Employment Agency (Bundesagentur für Arbeit 2018), while the requirements of Eurowings Discover and Condor are available on the portal career.aero (EW Discover 2021) and on the Condor website (Condor n.d.), respectively. The identified, most frequently required competencies were also transferred into the ESCO scheme. The findings are summarized in Section 4.2.

In addition, we sometimes also refer to the first author's own experience, where necessary, to generate, supplement and discuss the results. This allows us to consider the everyday working environment and routines of flight attendants and associated requirements that are often not described in the (limited) literature. Her professional experience as a cabin crew member is briefly summarized here:

- Flight attendant with Lufthansa German Airlines on long and short-haul flights for 16 years, including 12 years as purser;

- Part-time function in an operational support team at Lufthansa headquarters since 2009 , acting as an intermediary between flight operations, senior cabin crew management and flight crews to ensure timely and orderly flight operations despite unforeseen challenges in daily operations. 


\subsection{Survey-Based Determination of the Actual Future Competencies of German-Speaking Flight Attendants}

The presumed competencies and competence gaps from the above-described deskresearch were empirically examined by means of an online survey of 273 flight attendants of the airlines Lufthansa, Swiss, Condor, Lufthansa Cityline, Eurowings, TUIfly, Austrian Airlines, Brussels Airlines, EasyJet and MHS Aviation in the period from 15 to 30 April 2021. For this purpose, the (potential) participants had been approached via social media, such as private Facebook groups open to flight attendants only.

The German-language questionnaire was created using the online survey software (EFS Survey) from QuestBack GmbH. It was, and-at the time of writing-still is, available via the link https:/ / ww2.unipark.de/uc/Students/7a31/ (accessed on 13 December 2021). It contained a total of 27 quantitative questions, ten of which also allowed for open answers. A pdf version of the questionnaire is attached to this paper as supplementary material.

The first questions covered the respondent's current job status, such as airline affiliation/employer, job experience (in years) and rank in the cabin (flight attendant or chief flight attendant (purser)), as well as language skills (number of additional languages spoken at B1 or higher level, besides German and English). These questions also served as easy-to-answer (icebreaker) questions in order to keep the motivation to continue answering the questionnaire at a high level.

To get an idea of which competencies are important for their jobs, the participants were then asked to individually rate the importance of 20 given single competencies for their occupation. This evaluation was done using a five-point scale from unimportant to important. As the names of the future competencies in the ESCO scheme are not necessarily self-explanatory, we decided to have the participants rate in the questionnaire such competencies that are easy to understand and/or commonly known and that are at the same time, repeatedly mentioned in the selected literature as examples of future competencies, and accordingly derived these 20 competencies available for selection from Kirchherr et al. (2018) and from the requirements according to the airline job advertisements. Moreover, the ESCO scheme sometimes combines skills into higher-level competencies, whereas it was clearer to ask participants for individual skills.

For these reasons, we have not considered it useful to map the ESCO scheme directly 1:1 in the questionnaire. In order to ensure that all participants have the same-or at least a very similar-understanding of the competencies to be assessed, we briefly explained each skill mentioned in the questionnaire, partly using the definitions from the sources mentioned above.

To identify actual and potential sectors outside the aviation industry, which could be of relevance for flight attendants deciding to leave the sector, the next set of questions dealt with current (part-time) activities and further training. More specifically, respondents were first asked whether they currently had a second, part-time job, and if so, in which sector. Next, the participants were asked if they were currently continuing their education, and at what level (with predetermined answers from "simple" training, e.g., in software or language skills, to formal vocational training or university studies) and in which sector.

To determine the actual relevance of job changes for flight attendants, the subsequent part of the survey asked if respondents had already considered quitting their jobs as flight attendants before the pandemic and whether they were currently looking for a new job. In order to identify which sectors and occupations the flight attendants feel qualified for, the next questions then aimed to find out from the flight attendants in which sector and in which specific function/job within this sector they see their greatest potentials for a job change.

The next block of questions dealt with the general understanding of future competencies and their importance from the perspective of the employer in general, outside the aviation sector, from the perspective of the flight attendants. Participants were first asked to use a five-point scale from unimportant to important to rate the importance of such competencies, which were again derived from Kirchherr et al. (2018). After that, 
respondents could select up to five skills they considered most important for the sector in which they saw their greatest potential for a job change, as previously identified.

The next set of questions then asked the respondents to assess themselves in terms of their future skills. Here, participants had the possibility to self-evaluate their own competencies and the likelihood that they would improve these. For the self-assessment of existing competencies, for better understanding, the participants were confronted with competence-specific statements (without directly naming the individual competencies) and asked to what extent they could identify with these statements (five-point scale from "does not apply at all" to "does fully apply"). For the assessment of the likelihood to improve the competencies, another five-point scale from "not at all likely" to "very likely" was used.

The closing questions covered socio-demographics, such as sex, age, highest level of education, sector (in case of completed vocational training) and subject area and exact academic level (in case of academic degree). The survey results are summarized in Section 4.3, while Section 4.4 identifies competence overlaps and gaps.

\section{Results}

\subsection{Key Future Skills}

The most frequently mentioned future competencies in the aforementioned studies relate to the specific ESCO skills and competencies "programming computer systems" (mentioned 11 times), "working with computers" (9), "communication, collaboration and creativity" (24), "solving problems" (9) and "adapt to change" (10) (Figure 2).

As the figure shows, nine out of the ten studies in the sample mention "digital literacy" as an individual competence from the specific ESCO skills and competencies categories "working with computers". A total of eleven different single competencies from the ESCO category "programming computer systems", such as web or blockchain development or user-centered design, are mentioned in four different studies. This shows that the skill and competence category "programming computer systems" is considered a future competence by fewer studies, while it includes a broader range of related individual competencies.

"Communication, collaboration and creativity" are three competencies that should not be viewed individually as they are often interlinked (Koch 2017, p. 26). ESCO, therefore, groups them into one skill and competence category and defines them as follows: "Communicating, collaborating, liaising, and negotiating with other people, developing solutions to problems, creating plans or specifications for the design of objects and systems imparting knowledge to others" (ESCO 2020b). All of the ten sources mention at least one, and in total 24, of the individual competencies related to this ESCO category, including "collaboration" (seven), "communication skills" (six), "creativity" (five) and "innovation" (five).

All but one of the studies consider "solving problems" as a widely required future competence, irrespectively of the actual position or industry.

Finally, seven of the studies consider at least one of four different competencies as crucial, which are summarized by ESCO under the term "adapt to change". These are "adaptability" (mentioned three times), "change competence" (three), "agile working" (one) and "flexibility" (two).

\subsection{Job Requirements for Flight Attendants in Germany}

The transformation of the identified, most frequently required competencies of flight attendants according to job advertisements results in a largely uniform requirement profile for flight attendants, which focuses on the specific ESCO skill and competence categories "communication, collaboration and creativity" (eight mentions), "using foreign languages" (seven), "working in teams" (five), "cope with pressure" (five), "providing general assistance to people" (five) and "meet commitments" (four) (Figure 3). 


\begin{tabular}{|c|c|c|c|c|c|c|c|c|c|c|c|}
\hline & & Source & \begin{tabular}{c|} 
Lufthansa \\
CityLine
\end{tabular} & Eurowings & TUlfly & Easylet & Lufthansa & Condor & $\begin{array}{l}\text { Eurowings } \\
\text { Discover }\end{array}$ & \begin{tabular}{|c|} 
Sum of \\
compe- \\
tencies \\
mentioned \\
\end{tabular} & \begin{tabular}{|c|} 
Sum at \\
ESCO level
\end{tabular} \\
\hline $\begin{array}{l}\text { General skills \& } \\
\text { competencies } \\
\text { according to } \\
\text { ESCO }\end{array}$ & $\begin{array}{l}\text { Specific ESCO skills } \\
\text { \& competencies }\end{array}$ & $\begin{array}{l}\text { Associated single } \\
\text { competencies }\end{array}$ & \multicolumn{9}{|c|}{ Frequency of mention } \\
\hline \multirow{3}{*}{$\begin{array}{l}\text { S1 - Communication, } \\
\text { collaboration and } \\
\text { creativity }\end{array}$} & $\begin{array}{l}\text { S1.0.0 - Communication, } \\
\text { collaboration and creativity }\end{array}$ & $\begin{array}{l}\text { Communication skills } \\
\text { Sociability }\end{array}$ & 1 & 1 & 1 & 1 & $\begin{array}{l}1 \\
1\end{array}$ & & $\begin{array}{l}1 \\
1\end{array}$ & $\begin{array}{l}3 \\
5\end{array}$ & 8 \\
\hline & s1.8.1 - Working in teams & Ability to work in a team & 1 & 1 & 1 & & 1 & & 1 & 5 & 5 \\
\hline & \begin{tabular}{|l|}
1.15 .1 - Using foreign \\
languages
\end{tabular} & Multilingualism & 1 & 1 & 1 & 1 & 1 & 1 & 1 & 7 & 7 \\
\hline S3 - Assisting and caring & $\begin{array}{l}\text { S3.4.4 - Providing general } \\
\text { assistance to people }\end{array}$ & High service orientation & 1 & 1 & & & 1 & 1 & 1 & 5 & 5 \\
\hline \multirow[b]{2}{*}{ A1 - Attitudes } & A1.4.0 - Cope with pressure & \begin{tabular}{|l|}
$\begin{array}{l}\text { Willingness to work under } \\
\text { stress, ability to work under } \\
\text { pressure (e.g. irregular working } \\
\text { hours) }\end{array}$ \\
\end{tabular} & 1 & 1 & 1 & & 1 & 1 & & 5 & 5 \\
\hline & A1.13.0 - Meet commitments & $\begin{array}{l}\text { Reliability } \\
\text { Sense of responsibility }\end{array}$ & & & $\begin{array}{l}1 \\
1\end{array}$ & & $\begin{array}{l}1 \\
1\end{array}$ & & & 2 & 4 \\
\hline
\end{tabular}

Figure 3. Competence requirements for flight attendants. Source: Own review of published airline job offers by Bundesagentur für Bundesagentur für Arbeit (2018), Condor (n.d.) and EW Discover (2021).

The specific ESCO skills and competence category "communication, collaboration and creativity" is explicitly required by all but one airline in the form of the single competencies "communication skills" (three mentions) and "sociability" (five mentions). According to the first author's own experience, international airlines, such as Lufthansa, usually try to mix crews on specific routes in a way that at least one or more crew members have the same ethnic or cultural background as the majority of passengers to improve the level of communication as a means to reduce cultural differences between the crews and their guests. Other aspects of "communication, collaboration and creativity" include abilities to pro-actively approach and talk with the passengers and the ability to collaborate in different teams towards the same result: safety and satisfied guests.

Although creativity is also part of this competence category according to ESCO, none of the airlines reported this skill explicitly as key requirement. For a uniform and consistent quality standard on all flights, most processes on board, such as service or emergency procedures, are heavily standardized and defined down to the smallest detail (Bentner 1998, p. 167). Working material, as well as the meal load, are individually calculated for each flight, depending on the number of passengers and/or a certain minimum stock (first author's own experience). Creativity is, therefore, usually not required onboard. However, there are also exceptions to the rule: creating a special meal that was mistakenly not delivered, as well as the competent handling of a passenger complaint, require not only tact/sensitivity but also creativity. Given the limited resources and possibilities, flight attendants need to think outside the box in such situations (first author's own experience).

"Working in teams" is explicitly required by five airlines; according to ESCO, this refers to "working confidently within a group with each doing their part in the service of the whole" and "understanding and respecting the roles and competencies of other team members" (ESCO 2020b). The ability to work in teams seems to be of particular importance as flight attendants have no time for team building. Depending on the size of the airline and the distribution of flights among flight attendants, the crew members often only get to know each other a few hours before departure. Instant team building in the shortest possible time is required, especially since the teams often work together for several days (Lufthansa 2020).

Given the international nature of the air transport business, all seven airlines require multilingualism, i.e., the use of foreign languages (at least English). Other competencies required are "high service orientation" (five mentions) as part of the ESCO skills and competence category "providing general assistance to people", and the ESCO categories "cope with pressure" (five mentions) and "meet commitments" (four mentions over the two single competencies "reliability" (two) and "sense of responsibility" (two). 


\subsection{Actual Competencies of German-Speaking Flight Attendants (Survey Results) 4.3.1. Socio-Demographics, Secondary Employment and Continuing Education}

Table 2 shows the distribution of participants according to socio-demographics, such as gender, age, language skills and highest level of education. The respondents are $80 \%$ female, more than two-thirds between 23 and 45 years old and $60 \%$ have completed vocational training (apprenticeship) and/or a university degree. A total of $27 \%$ of the respondents are pursers (chief flight attendants). Half of the participants speak more than two languages. A valid verification of the representativeness of the sample depicted in the survey for the entirety of flight attendants is not possible because airlines do not publish demographical data on their cabin crews (Bentner 1998, p. 122). Intuitively, however, the sample represents distributions as in a typical crew on long-haul flights according to the first author's own experience.

Table 2. Distribution of participants according to selected socio-demographic characteristics.

\begin{tabular}{|c|c|c|c|}
\hline Sex & Age (Years) & Highest Level of Education & \# Languages (min B1) \\
\hline $\begin{array}{l}\text { Female } 80 \% \\
\text { Male } 19 \% \\
\text { Diverse } 1 \%\end{array}$ & $\begin{array}{l}18-222 \% \\
23-2815 \% \\
29-3518 \% \\
36-4535 \% \\
46-5524 \% \\
>556 \%\end{array}$ & $\begin{array}{l}\text { Intermediate school-leaving certificate } \\
\text { ("Realschule") } 5 \% \\
\text { A-levels or Vocational baccalaureate 35\% } \\
\text { Apprenticeship } 25 \% \\
\text { University (of Applied Science) } 35 \%\end{array}$ & $\begin{array}{l}247 \% \\
322 \% \\
47 \% \\
53 \% \\
63 \% \\
>618 \%\end{array}$ \\
\hline
\end{tabular}

Work experience, secondary occupations and continuing training may indicate potential suitability of cabin crew members for other occupations. Almost $58 \%$ of respondents have a second, part-time job (Figure 4), mostly in health, sports, personal care (17\%), hospitality, tourism, event management (13\%) or business, languages and administration $(11 \%)$.

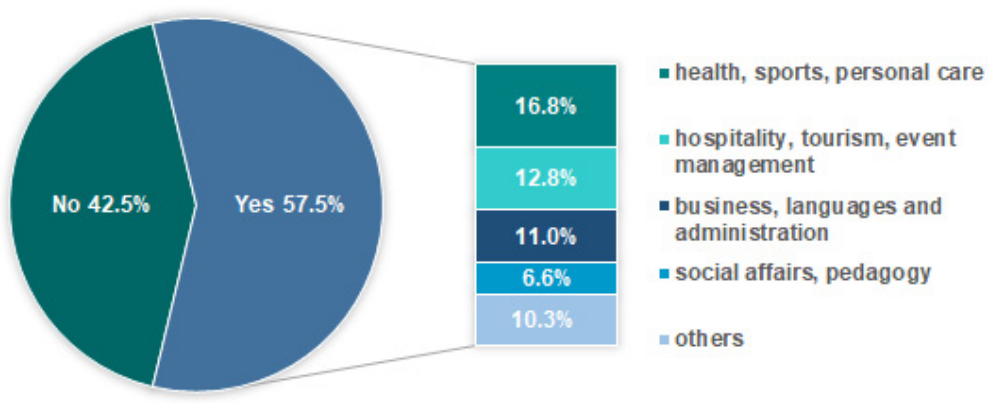

Figure 4. Secondary employment of flight attendants.

All participants aged 18-22 and almost three-quarters of respondents aged 23-28 have a second job alongside their job as a flight attendant, but only $41 \%$ of those aged 55 and over. The rate of secondary employment seems to decrease with increasing age (Figure 5).

With $45 \%$, the share of cabin crew members with continuing education in the sample (Figure 6) is below the German average from 2018 of 54\% (BMBF-Bundesministerium für Bildung und Forschung 2019, p. 13). More than a quarter of the flight attendants participating in the survey are part-time students, $8 \%$ are in an apprenticeship and 5\% are improving their language skills. Another $29 \%$ are considering further education. The COVID-19 pandemic is referred to as a reason for this by one out of five flight attendants who are undergoing further training. 


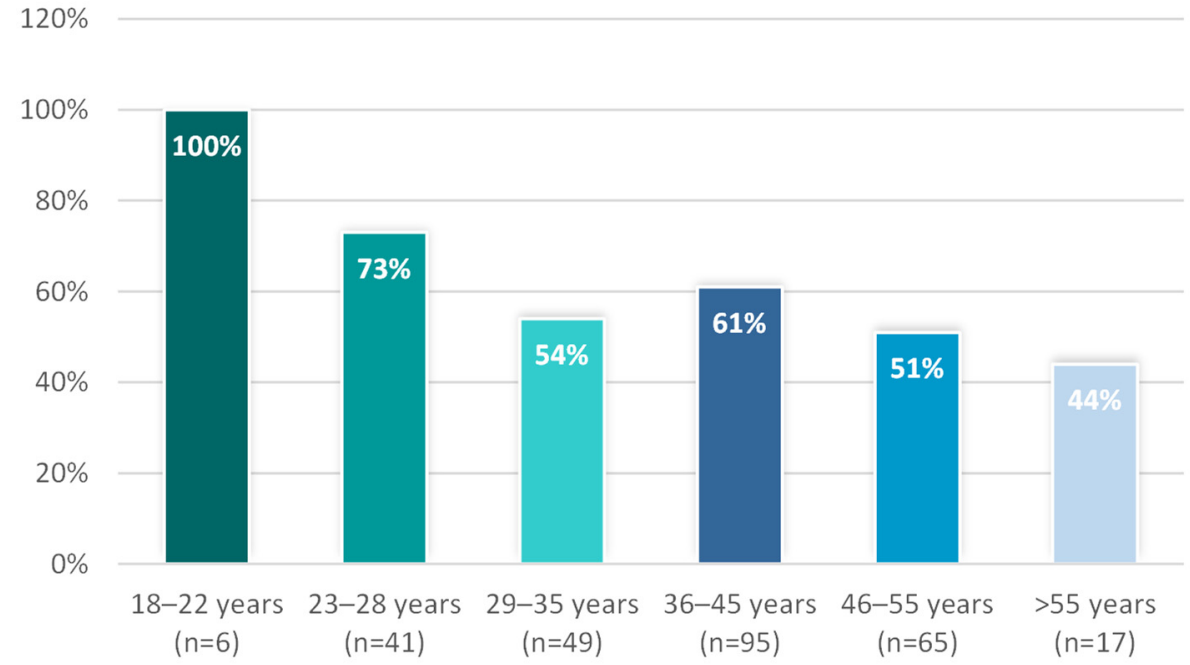

Figure 5. Secondary activities of flight attendants by age group.

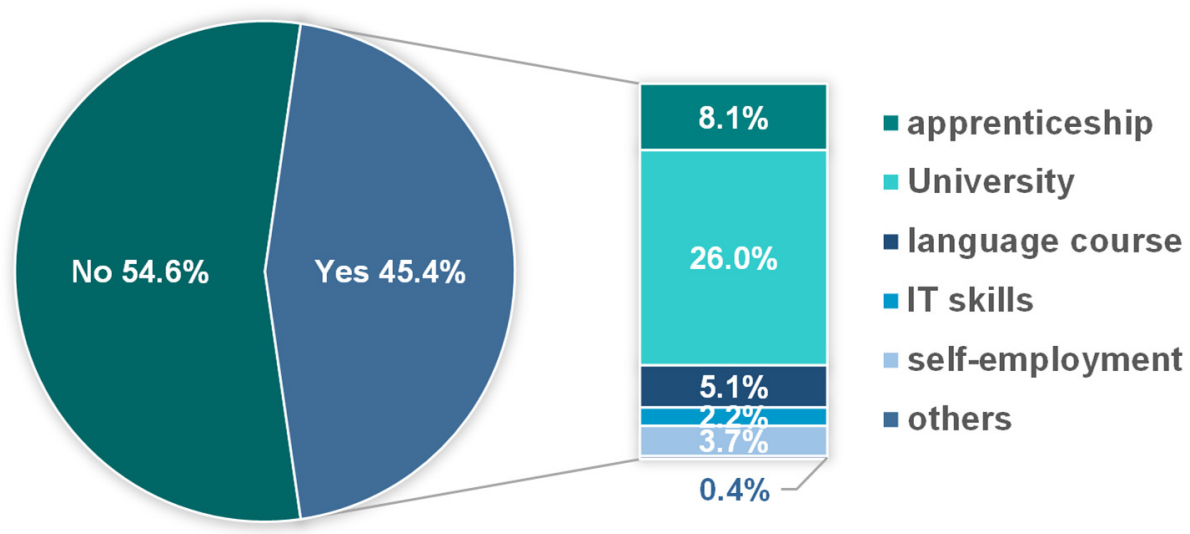

Figure 6. Continuing training of flight attendants.

The remaining respondents had already started further training before the outbreak of the COVID-19 pandemic. Of the 54.6\% without further training shown in Figure 6, 29\% are thinking of starting further training. The COVID-19 pandemic is cited as the trigger for this. For the remaining $25 \%$ of the cabin crew, the possibility of further training is currently not an issue.

Despite the COVID-19 pandemic, one-third of the total sample sees the highest probability of success for a job change in the "lockdown-affected" hospitality, tourism, event management and home economics sectors. Other sectors also frequently mentioned are business, administration and languages, as well as social work and education.

\subsubsection{Importance of Competencies from a Cabin Crew Perspective}

The ability to work in a team, communication skills, the ability to deal with conflicts, reliability and service orientation are each rated as important by over $90 \%$ of the survey participants, while digital and technological skills, such as "IT expertise, software programming" and "digital literacy" are considered almost unimportant (Figure 7). 


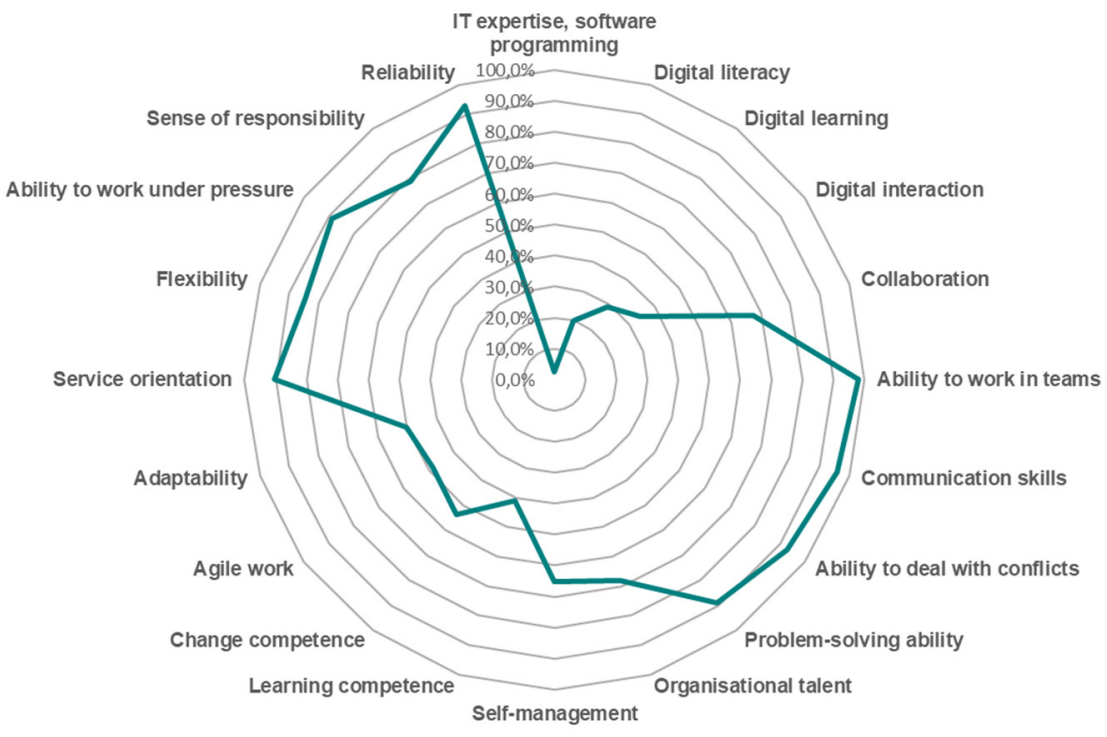

Figure 7. Importance of competencies for cabin crews.

\subsubsection{Competence Self-Assessment}

Structured in accordance with ESCO, Figure 8 shows the results of this self-assessment for the individual future competencies that were identified as most relevant in the selected literature.

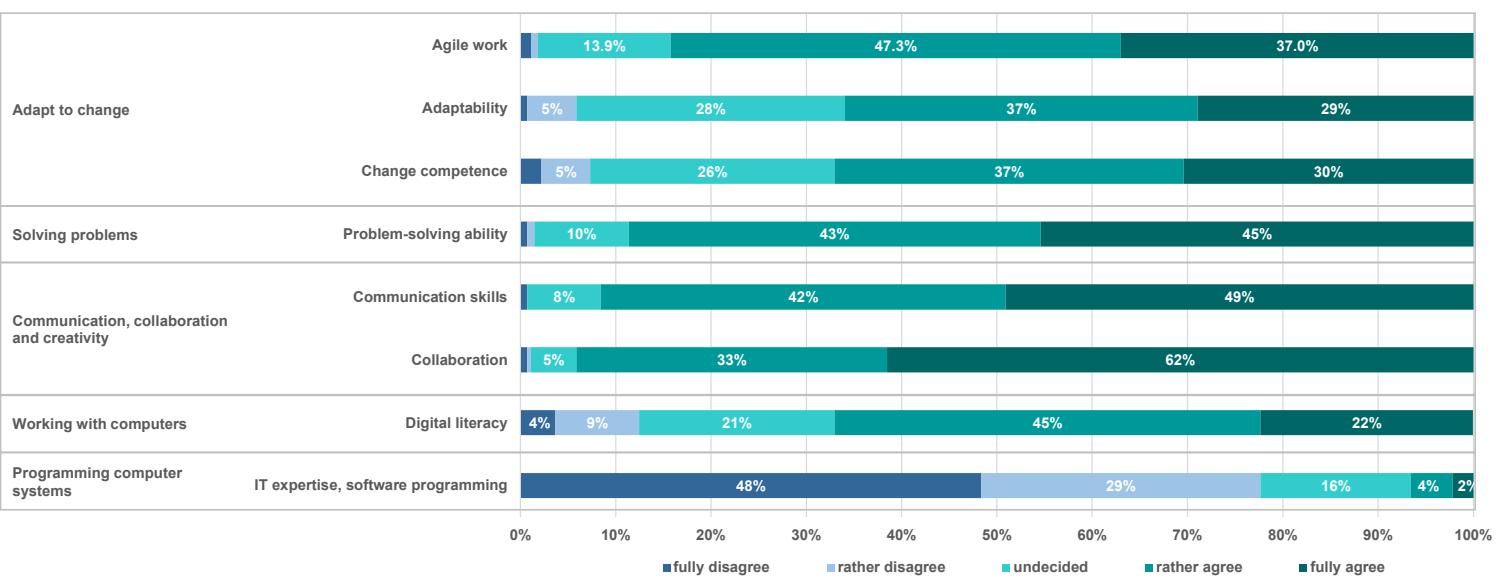

Figure 8. Future skills self-assessment of flight attendants.

Most flight attendants state that they fulfill the future competence "communication, collaboration and creativity". The highest self-assessments are given for the individual competencies "collaboration skills" with 95\% and "communication skills" with 91\% if the percentages for "fully agree" and "rather agree" are added. A total of $62 \%$ of the participants are convinced that they are fully able to collaborate, but only just under half of the respondents state that they are fully able to communicate-which elsewhere in the survey is rated by $80 \%$ of the participants as the most important individual competence for the general labor market.

"Solving problems" is something that $43 \%$ of the respondents are rather, and $45 \%$ completely, confident in. Thus, with a cumulative $88 \%$, this ESCO competence has the second-highest overall fulfillment.

For the future competence "adapt to change", a mixed picture emerges: the approval rates for the individual competencies "change competence" and "adaptability" are very close to each other as, for both, about two-thirds of the respondents state that the corresponding statements apply to them "completely" or "rather". At the same time, $28 \%$ 
and $26 \%$ of the respondents are undecided. The situation is different for "agile working". Although agile working refers to a methodology of working that, in the first author's own experience, has little relevance in the context of flight attendant daily work, almost $85 \%$ of the participants are "fully" or "rather" convinced that they have this competence.

In the self-assessment, the ESCO competencies "Working with computers" and "Programming computer systems" receive the lowest approval ratings of $22 \%$ and $45 \%$, respectively, with this many individuals being confident in basic digital skills, including handling personal data and using common software products without or with slight limitations, while a cumulative 13\% reach their limits here. Advanced IT knowledge, especially in the area of programming, is not, or barely, present in more than $75 \%$ of the participants and only fully present in $2 \%$.

Finally, Figure 9 shows the extent to which individual cabin crew members claim to possess more than one of the identified future competencies. Only $1 \%$ or just under $5 \%$ of the participants seem to fulfill each of the five future competencies "fully" or at least "rather or fully". If "programming computer systems" (PCS) were completely left out of the analysis, these percentages would increase to just under $5 \%$ and $37 \%$ for the other four future competencies. If IT skills (PCS and "working with computers" (WwC)) were completely disregarded, almost half of the respondents could state that they meet three future competencies at least with slight limitations, and 79\% would see themselves as largely competent at least in the competence fields of "communication, cooperation and creativity" and "solving problems".

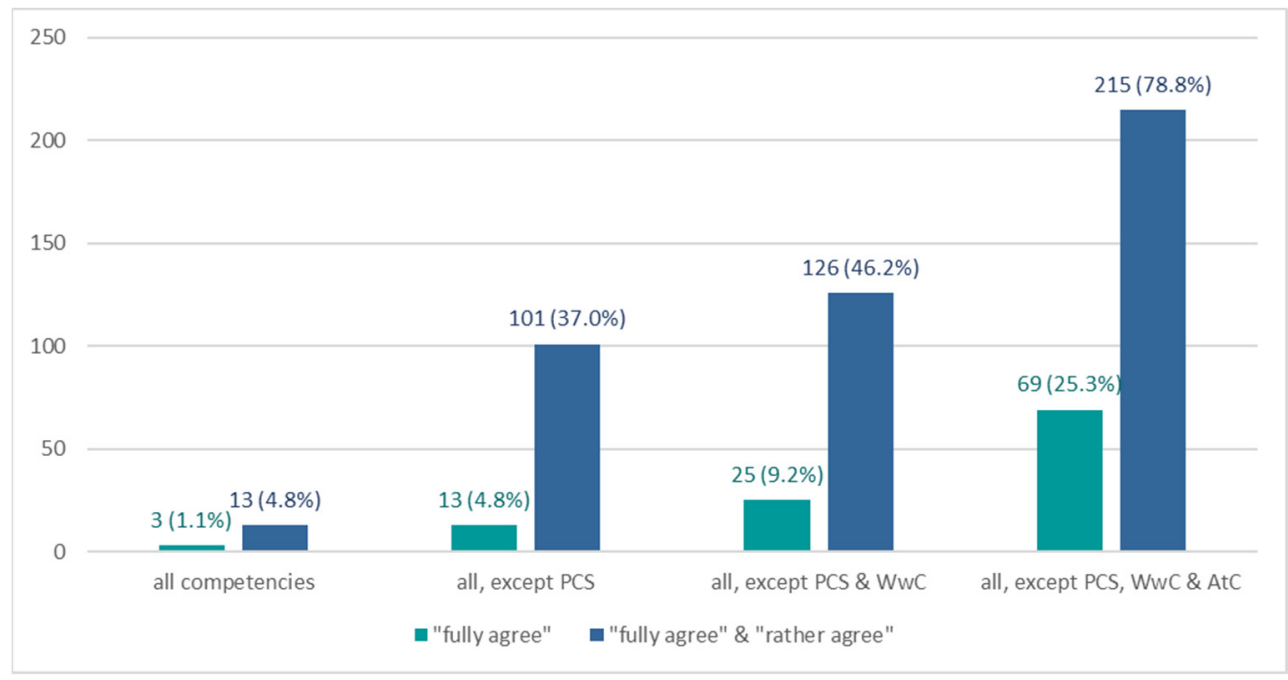

Figure 9. Fulfillment of future competencies by flight attendants (self-assessment). PCS = programming computer systems; $\mathrm{WwC}=$ working with computers; AtC $=$ adapt to change.

\subsection{Flight Attendants: Future Competence Overlaps and Gaps}

A comparison of the requirement profile for flight attendants (as presented in Section 4.2) with the key future competencies that were identified from the studies used as references (Section 4.1) shows that the profiles only match in the competence area "communication, collaboration and creativity" (and here in the single competence "communication skills", to be more precise) but diverge in all other areas (Table 3, columns A and B). 
Table 3. Comparison of key future competencies and requirement profiles and fulfillment of flight attendants.

\begin{tabular}{|c|c|c|c|c|c|}
\hline $\begin{array}{l}\text { Specific ESCO } \\
\text { Skills \& } \\
\text { Competencies }\end{array}$ & $\begin{array}{l}\text { Associated Single } \\
\text { Competencies }\end{array}$ & $\begin{array}{c}\text { [A] } \\
\text { Essential future } \\
\text { Competency } \\
\text { According to } \\
\text { Literature Review }\end{array}$ & $\begin{array}{c}\text { [B] } \\
\text { Airline } \\
\text { Requirement } \\
\text { Profile for Flight } \\
\text { Attendants }\end{array}$ & $\begin{array}{c}{[\mathrm{C}]} \\
\text { Flight Attendant } \\
\text { Self-Assessment of } \\
\text { Required } \\
\text { Competencies }\end{array}$ & $\begin{array}{c}{[D]} \\
\text { Flight Attendant } \\
\text { Self-Assessment of } \\
\text { Own (Future) } \\
\text { Competencies }\end{array}$ \\
\hline $\begin{array}{l}\text { S5.1-Programming } \\
\text { computer systems }\end{array}$ & $\begin{array}{l}\text { IT expertise, software } \\
\text { programming }\end{array}$ & $\mathrm{x}$ & & $3 \%$ & $2 \%$ \\
\hline $\begin{array}{l}\text { S5.0-Working with } \\
\text { computers }\end{array}$ & Digital Literacy & $\mathrm{x}$ & & $20 \%$ & $22 \%$ \\
\hline \multirow{3}{*}{$\begin{array}{l}\text { S1.0.0- } \\
\text { Communication, } \\
\text { collaboration and }\end{array}$} & Collaboration & $\mathrm{x}$ & & $67 \%$ & $62 \%$ \\
\hline & Communication skills & $x$ & $x$ & $96 \%$ & $49 \%$ \\
\hline & Sociability & & $x$ & - & - \\
\hline $\begin{array}{l}\text { S1.9-Solivity } \\
\text { problems }\end{array}$ & Problem-solving ability & $\mathrm{x}$ & & $89 \%$ & $45 \%$ \\
\hline $\begin{array}{c}\text { S1.8.1-Working in } \\
\text { teams }\end{array}$ & Ability to work in a team & & $\mathrm{x}$ & $98 \%$ & $68 \%$ \\
\hline $\begin{array}{l}\text { S1.15.1-Using } \\
\text { foreign languages }\end{array}$ & Multilingualism & & $\mathrm{x}$ & $100 \%$ & $100 \%$ \\
\hline $\begin{array}{l}\text { S3.4.4-Providing } \\
\text { general assistance to } \\
\text { people }\end{array}$ & High service orientation & & $x$ & $90 \%$ & $47 \%$ \\
\hline $\begin{array}{l}\text { A1.4.0-Cope with } \\
\text { pressure }\end{array}$ & $\begin{array}{l}\text { Willingness to work } \\
\text { under stress, ability to } \\
\text { work under pressure (e.g., } \\
\text { irregular working hours) }\end{array}$ & & $\mathrm{x}$ & $89 \%$ & - \\
\hline \multirow{2}{*}{$\begin{array}{l}\text { A1.13.0-Meet } \\
\text { commitments }\end{array}$} & Reliability & & $x$ & $93 \%$ & - \\
\hline & Sense of responsibility & & $\mathrm{x}$ & $79 \%$ & - \\
\hline \multirow{3}{*}{$\begin{array}{l}\text { A1.1.0_-Adapt to } \\
\text { change }\end{array}$} & Change competence & $\mathrm{x}$ & & & $30 \%$ \\
\hline & Agile working & $\mathrm{x}$ & & & $37 \%$ \\
\hline & Adaptability & $\mathrm{x}$ & & & $29 \%$ \\
\hline
\end{tabular}

This comparison indicates a potentially rather low level of future competencies among flight attendants. In particular, information technology skills are missing in the job requirements, which suggests that the future skills areas "programming computer systems" and "working with computers" are especially not relevant for everyday work and could, therefore, represent skills gaps for many cabin crew members.

Table 3 further compares the importance of future competencies in the eyes of the flight attendants (column C), according to the survey results from Section 4.3, the competencies as required by the airlines (column $\mathrm{B}$ ) and the future competencies considered important in the aforementioned literature (column A).

The majority of airlines' and flight attendants' assessments of the importance of the required competencies for flight attendants seem to match. A significant exception is the "problem-solving ability", which is rated as important by $89 \%$ of respondents but is not mentioned in the job descriptions of the airlines. A total of $20 \%$ and $3 \%$ of flight attendants, respectively, consider the competencies "working with computers" and "programming computer systems" as important, although flight attendants usually have little to no contact with them in their daily work.

Column D then contains the results of the flight attendants' competence self-assessment. The percentages represent the shares of respondents who indicated that they fully met the competence in question.

The most common competence is "using of foreign languages", as all airlines require at least bilingualism from their employees as a recruitment criterion. When further comparing the self-assessments in column $\mathrm{D}$ with the individual competencies required by airlines in column B, it shows that every other cabin crew member has stated not to fully meet "high service orientation", although $90 \%$ of the respondents and the airlines consider this individual competence important. 
With regard to the essential future competencies and the associated individual competencies as indicated in column $\mathrm{A}$, the results of the self-assessment are also mixed. When considered independently, about two-thirds of the flight attendants believe that they have very good knowledge in the areas of teamwork and collaboration skills. Almost half of the respondents consider communication and problem-solving skills to be among their strengths. Only one-third believe that they fully achieve the required level in the individual competencies of agile working, change competence and adaptability. According to self-reporting, about one in five flight attendants has good basic digital skills, whereas only some have advanced IT skills in the field of "programming computer systems".

\section{Discussion}

\subsection{Key Future Skills}

As summarized in Section 4.1, "programming computer systems", "working with computers", "communication, collaboration and creativity", "solving problems" and "adapt to change" were identified as the key future competencies in the ten selected studies.

\subsubsection{Working with Computers and Programming Computer Systems}

The Internet and technological progress, in general, have long been determining everyday working life across most industries. Today, digital and technological knowledge refer to a much wider framework than using application software, such as Microsoft Word, Excel or PowerPoint, for example. The careful handling of personal data (data protection), an appropriate tone in digital media, filtering out important and correct information from the Internet or digital learning are just some of today's expected digital skills (Kirchherr et al. 2018, pp. 5-6). Since the outbreak of the COVID-19 virus, numerous companies and employees have been allowing, or even forcing, their employees to work from home (Ahlers et al. 2021, p. 3). As work becomes more digital, it is important that as many employees as possible master basic digital skills (Kirchherr et al. 2018, p. 5).

On the one hand, this illustrates how quickly the relevance of "working with computers" has increased since the outbreak of the COVID-19 pandemic. On the other hand, it is obvious that the competence of working with computers will continue to gain in importance in the course of advancing digitization.

"Programming computer systems", in contrast, is a highly sought-after competence, which, however, seems to be a requirement for a smaller number of occupations. This is reflected in the outcome of the literature review, where competence in this category is only mentioned as future competencies in four out of the ten studies.

\subsubsection{Communication, Collaboration and Creativity}

Six out of ten sources in the literature comparison name communication as one of the most important competencies for the future world of work. Nowadays, information is increasingly shared on internal knowledge platforms, which also require an increase in communication and cooperation skills (Hammermann and Stettes 2016, p. 16). In this case, communication skills and collaboration are closely related. Developments, such as the division of workplaces (job sharing), project work and working from home, also create new requirements for the exchange of knowledge within organizations (Schönfelder 2018, p. 58). Successful cooperation between decentralized teams, therefore, requires a high degree of collaboration.

Creativity is classified as a future competence in five of the ten studies. Alex Gray, from the World Economic Forum, justifies this selection as follows: "Creativity is becoming one of the three best skills workers need. With the avalanche of new products, new technologies and new ways of working, workers need to become more creative to benefit from these changes" (Gray 2016). In the new world of work 4.0, which is characterized by technology and digitization, creativity plays a decisive role when it comes to further innovations.

In summary, advancing digitalization enables new and faster forms of communication and thus drives a change in the areas of communication and collaboration even across 
company boundaries (Grimm 2009, p. 22). Scheunemann is also convinced that creativity should be actively promoted and developed in organizations in order to be able to face new challenges in a constructive way (Scheunemann 2018, p. 247).

\subsubsection{Solving Problems}

All but one of the studies consider "solving problems" as a widely required future competence. This is not surprising as, e.g., the OECD, assumes that interdisciplinary thinking will increasingly be necessary in order to obtain a variety of solutions to complex problems (OECD 2019, p. 64). Complex problems of today can often no longer be solved with old methods but require a deeper thinking power, while more and more routine tasks are carried out by robots or machines.

Therefore, the demand for employees with problem-solving competence increases. The competence to solve such complex problems is closely related to critical thinking and creativity (OECD 2019, p. 45). This is also reflected in the ESCO model, where the specific ESCO skill and competence categories "solving problems" and "communication, cooperation and creativity" are ultimately assigned to the same super-category.

\subsubsection{Adapt to Change}

ESCO combines four single competencies to describe the skill and competence category "adapt to change". The four individual competencies, adaptability, ability to change, agile working and flexibility, refer to the fact that employees "must rather be prepared for challenges in the future that we do not know today, for professions that do not yet exist, for the use of technologies that have not yet been developed" (Sauter et al. 2018, p. 2).

As globalization and digital transformation are driving the spatial and temporal flexibilization of work forward (BMAS-Bundesministerium für Arbeit und Soziales 2017, p. 15), the complexity of the newly emerging problems requires employees to try out new ways and take on greater responsibility (Sauter et al. 2018, p. 25). In order to continue to be attractive and valuable for employers, it is, therefore, important for employees to keep their qualifications up to date or to adapt them to the latest requirements (Rump and Eilers 2017, p. 91).

\subsection{Future Competence Overlaps and Gaps of Flight Attendants}

Section 4.4 compared the key future competencies, as derived from the ten literature sources, with the required and actual competencies of the flight attendants, as identified from the airline job advertisements and the survey, to identify competence gaps and overlaps. The results are illustrated in Table 3.

The required competencies, as perceived by the respondents, on the one hand, and according to the job advertisements, on the other hand, match to a large extent. Due to a lack of literature, there is only limited scope for comparisons with existing papers. However, a comparison with the results from Kim and Park (2014) reveals that the Korean flight attendants seem to rank appearance and attitude more important than their German colleagues and the German airlines, while other competence areas, such as social/interpersonal and language skills, seem to be regarded as important "everywhere".

Most flight attendants fulfill the future competencies "communication, collaboration and creativity" and "solving problems". In combination with the extensive language skills of flight attendants, these are likely to make an important starting point for a reorientation of the labor market. "Solving problems" is something that $43 \%$ of the respondents are rather, and $45 \%$ are completely confident in (Figure 8 ). Thus, with a cumulative $88 \%$, this ESCO competence has the second-highest overall fulfillment. This is somewhat surprising as this competence is not mentioned in the job descriptions of the airlines, while $89 \%$ of the cabin crew members participating in the survey (see Figure 7) consider this competence important for their job.

In the self-assessment, the ESCO competencies "Working with computers" and "Programming computer systems" receive the lowest agreement values, as previously assumed. 
While more than two-thirds of the respondents consider themselves to have skills in the competence areas "adapt to change" and "working with computers", the proportion of those who (tend to) not or only partially trust themselves to work with computers is significantly higher than for the other competencies. This group may not have sufficient skills and knowledge to survive in the world of work 4.0.

"Working with computers" can, therefore, be regarded as an important field of development for many flight attendants. Although digitalization has also found its way onboard aircraft, its influence on flight attendants and their work processes has so far been rather limited. For some years now, airlines have been providing their employees with tablets with which they have access to all official apps and documents, employee portals or e-mails. For most flight attendants, the tablet is, therefore, the only work tool with which digital work is performed. Otherwise, a flight attendant has little job-related contact with computers, let alone with programming (first author's own experience).

Accordingly, the competence "programming computer systems" does not play a role for most flight attendants, which is why only a small fraction of the observed group of flight attendants has sufficient skills in all five competence fields. However, "programming computer systems" can most likely be considered a specialized future competence. This view is also supported by the results of the review of the ten selected studies where programming skills are mentioned as a future competence in only four of them.

\section{Conclusions}

"Future competencies" are important skills that are fundamentally independent of the actual industry where an employee works or intends to work, and that are supposed to gain importance in the future. In other words: future competencies are supposed to be of relevance for many different industries, in addition to any sector or taskspecific specialist knowledge and capabilities. Applying the European "ESCO" (European Skills/Competencies, qualifications and Occupations) classification, a review of ten recent general studies on future competencies reveals "programming computer systems", "working with computers", "communication, collaboration and creativity", "problem solving" and "adapt to change" as the top five future skills needed across industries. These competencies are largely in line with the key future competencies mentioned in the above-mentioned literature on future competence requirements (e.g., communication skills, flexibility and technical and software skills) in service sectors (e.g., Gatta et al. 2009) and other complex industries, such as the maritime sector (Cicek et al. 2019).

On the basis of this concept, it is reasonable to assume that the job prospects of flight attendants with such competencies are also more diverse than initially assumed, despite a lack of state-recognized training. In view of the COVID-19-related job losses in the airline industry, future competencies can be seen as the basis for fundamentally new employment opportunities within and outside the industry. Therefore, the question of which future skills flight attendants actually possess is of high relevance. A review of airline job requirements for flight attendants and a survey among $n=273$ German-speaking cabin crew members suggest that flight attendants possess some of the future skills most frequently identified in key studies on future competencies, as well as extensive language skills, but have deficits in "working with computer systems" and "programming computer systems".

\subsection{Recommendations}

Airlines could - and should - train some of their flying personnel for (at least temporary) flexible deployment for other activities within (and also outside) the company. This may include switching qualified flight attendants to project work in other departments, e.g., in the low (mostly winter) season, and would it make it easier for them to terminate their activity as flight attendants completely if needed.

For the majority of flight attendants, the development and further training of their own (basic) computer skills should improve their chances in the labor market. In this 
context, other competencies, such as teamwork, learning skills and digital interaction, are certainly also helpful.

From a political point of view, improved incentives could be created for companies and employees to train the latter continuously in the area of future competencies, for example, through improved tax deduction possibilities or more targeted designs of educational leaves. According to the German Law for Further Education of Employees (Arbeitnehmerweiterbildungsgesetz, AWbG), employees in Germany can receive five days of company leave "for the purpose of socio-political learning and professional training" (Batzel 2017). In this context, further training measures (within the framework of) future competencies should be promoted both by the public and private players at any time in the sense of "lifelong learning", without an actual necessity (such as unemployment) being directly given, in order to also be able to counteract impending unemployment more quickly or more effectively.

Another issue that should be addressed is the fact that the flight attendant profession requires only airline-specific training courses but no formal, state-recognized vocational training or apprenticeship. As a result, many flight attendants- $40 \%$ in our sample (see Table 2) — do not possess any state-recognized formation, such as a university degree or apprenticeship. A viable approach to create a "safety net" for them could be to award them with a state-recognized bachelor's degree or vocational training equivalent after a certain number of proven years "on the job" combined with proven continuing formation courses training in future skills, such as computing. This recommendation should also be viewed in the light of the fact that long-serving flight attendants have paid taxes, but in return, not necessarily benefited from state-funded post-school education and thus not burdened the state budget for their professional education.

This aspect is also applicable to pilots and to employees in other industries who are engaged in a non-state-recognized, self-financed profession. Examples in Germany range from real estate agents over healing practitioners to dance teachers. Hence, our approach and the idea behind it may not only be applicable to flight attendants alone, but also to employees in other industries, including those with other non-state-recognized jobs. This could be further investigated in future research.

\subsection{Limitations}

The conclusions and recommendations drawn here are based on the premise that the flight attendants' self-assessments allow conclusions to be drawn about the actual fulfillment of competencies and that the future competencies identified here are actually used as decisive criteria by companies when selecting employees. We have no concrete, empirical information on the actual use of future skills in employee selection by companies, but Kirchherr et al. (2020) state that the so-called "future skills" they already identified in 2018 had currently gained even more importance, especially through COVID-19.

Moreover, our (limited) look at the literature on future competencies required by service industry employees in other sectors, such as the academic reference librarians in New Zealand (Chawner and Oliver 2013) and US low-wage service employees in general (Gatta et al. 2009) suggests an actually high practical relevance of such competencies.

In addition, there are other (potential) limitations of our research: first, one might wonder whether the selected ten sources provide a complete picture of future competencies, as discussed in the literature. Our literature review indicates that the selected studies seem to represent the literature quite well, as other sources we analyzed hardly discuss any additional competencies not considered here. Moreover, we have focused on the most frequently mentioned competencies anyway. Nevertheless, the process to identify and select the ten studies was not systematic.

Second, we see methodological limitations stemming from the survey design, sample selection and execution: According to trade union "Unabhängige Flugbegleiter Organisation (UFO) e.V." (information received upon request by e-mail on 24 November 2021), some 28,500 flight attendants are currently based in Germany. Hence, the sample size (n 
$=273$ ) can be regarded as too small, as for this population size a confidence level of $95 \%$ and a margin of error of $5 \%$ would suggest a sample size of at least 380 respondents. In addition, as the invitations to participate in the survey had been distributed by e-mail and social media, a bias towards younger flight attendants with a relatively higher knowledge of IT seems plausible.

Future research should take these limitations into account and could, as already suggested above, also be extended to the situation of workers without a state-recognized qualification in other sectors. On a more operational level, future research on the (re)qualification of flight attendants could address issues, such as more flexible switching between ground and cabin jobs.

Supplementary Materials: The following are available online at https:/ /www.mdpi.com/article/10 .3390/admsci11040154/s1.

Author Contributions: Conceptualization, K.F.B. and S.U.M.; literature review, K.F.B. and S.U.M.; methodology and survey conduction, K.F.B.; validation, K.F.B.; discussion of results, K.F.B. and S.U.M.; data curation, K.F.B.; writing—original draft preparation, German language, English translation and review, K.F.B.; writing-review, English translation, additional sections and editing, S.U.M.; visualization, K.F.B. and S.U.M.; supervision, S.U.M. All authors have read and agreed to the published version of the manuscript.

Funding: This research received no external funding.

Institutional Review Board Statement: Not applicable.

Informed Consent Statement: Not applicable.

Data Availability Statement: The data presented in this study are available on request from the corresponding author.

Conflicts of Interest: The authors declare no conflict of interest.

\section{References}

Agut, Sonia, Rosa Grau, and José María Peiro. 2003. Competency needs among managers from Spanish hotels and restaurants and their training demands. Hospitality Management 22: 281-95. [CrossRef]

Ahlers, Elke, Sandra Mierich, and Aline Zucco. 2021. Homeoffice. Was wir aus der Zeit der Pandemie für die zukünftige Gestaltung von Homeoffice lernen können. WSI Report 65. Available online: https:/ / www.boeckler.de/de/faust-detail.htm?sync_id=HBS007997 (accessed on 3 December 2021).

Anger, Christina, Enno Kohlisch, Oliver Koppel, and Axel Plünnecke. 2020. MINT-Herbstreport 2020. MINT-Engpässe und CoronaPandemie: Kurzfristige Effekte und Langfristige Herausforderungen. Gutachten für BDA, BDI, MINT Zukunft Schaffen und Gesamtmetall. Köln. Available online: https://www.iwkoeln.de/fileadmin/user_upload/Studien/Gutachten/PDF/2020 /MINT-Herbstreport_2020.pdf (accessed on 3 December 2021).

Babbar, Sunil, and Xenophon Koufteros. 2008. The human element in airline service quality: Contact personnel and the customer. International Journal of Operations \& Production Management 28: 804-30.

Bani-Salameh, Zakaria A., Muhammad K. Kabilan, and Lina Bani-Salalmeh. 2011. Utilising multimedia ESP programme in enhancing flight attendants' safety knowledge and problem solving skills. British Journal of Educational Technology 42: 1003-15. [CrossRef]

Batzel, Gisela. 2017. Berufsbildungsbegriffe Deutsch-Englisch. Terminologiesammlung für Berufsbildungsfachleute. Bonn: Bundesinstitut für Berufsbildung.

Bentner, Ariane. 1998. Durch die Welt zu fliegen und ziemlich frei zu sein. Beruf Stewardeß (Aktuelle Frauenforschung). Frankfurt am Main: Ulrike Helmer Verlag.

BMAS-Bundesministerium für Arbeit und Soziales. 2015. Grünbuch Arbeiten 4.0. Arbeiten Weiter Denken; Berlin: Bundesministerium für Arbeit und Soziales. Available online: https://www.bmas.de/SharedDocs/Downloads/DE/Publikationen/gruenbuch-arbeitenvier-null.pdf;jsessionid=5603D98B878B4F9D8AC29FEC483A7586. delivery1-replication?_blob=publicationFile\&v=1 (accessed on 28 September 2021).

BMAS-Bundesministerium für Arbeit und Soziales. 2017. Kompetenz- und Qualifizierungsbedarfe bis $2030 . \quad$ Ein gemeinsames Lagebild der Partnerschaft für Fachkräfte; Berlin: Bundesministerium für Arbeit und Soziales. Available online: https:/ / www.bmas.de/SharedDocs/Downloads/DE/Publikationen/a758-16-kompetenz-und-qualifizierungsbedarfe.pdf?_ blob=publicationFile\&v=1 (accessed on 7 December 2021).

BMBF-Bundesministerium für Bildung und Forschung. 2019. Weiterbildungsverhalten in Deutschland 2018. Ergebnisse des Adult Education Survey_AES-Trendbericht. Available online: https://www.bmbf.de/upload_filestore/pub/Weiterbildungsverhalten_ in_Deutschland_2018.pdf (accessed on 27 May 2021). 
Bonin, Holger, Terry Gregory, and Ulrich Zierahn. 2015. Übertragung der Studie von Frey/Osborne (2013) auf Deutschland: Endbericht. Forschungsbericht 455 (Bundesministerium für Arbeit und Soziales \& Zentrum für Europäische Wirtschaftsforschung (ZEW) GmbH, Hrsg.). Available online: https://ftp.zew.de/pub/zew-docs/gutachten/Kurzexpertise_BMAS_ZEW2015.pdf (accessed on 29 April 2021).

Bruckner, Laura, Simon Werther, Moritz Hämmerle, Bastian Pokorni, and Maik Berthold. 2018. Einleitung. In Arbeit 4.0 aktiv gestalten. Die Zukunft der Arbeit zwischen Agilität, People Analytics und Digitalisierung. Edited by Simon Werther and Laura Bruckner. Berlin: Springer, pp. 1-22.

Bruns, Catharina. 2018. Selbstständigkeit in der neuen Arbeitswelt: Entrepreneurship als Praxis für selbstbestimmte Arbeit und eine nachhaltige Wirtschaft. In Arbeitswelt der Zukunft. Trends-Arbeitsraum-Menschen-Kompetenzen. Edited by Harald R. Fortmann and Barbara Kolocek. Wiesbaden: Springer, pp. 264-81.

Bundesagentur für Arbeit. 2018. Flugbegleiterin/Flugbegleiter. Available online: https:/ /www.arbeitsagentur.de/vor-ort/fuerth/ download/1533716045164.pdf (accessed on 29 April 2021).

Bundesinstitut für Berufsbildung. 2015. Definition und Kontextualisierung des Kompetenzbegriffes. Available online: https: //www.bibb.de/de/8570.php (accessed on 29 April 2021).

Cattaneo, Alberto A. P., Chiara Antonietti, and Martina Rauseo. 2022. How digitalised are vocational teachers? Assessing digital competence in vocational education and looking at its underlying factors. Computers $\mathcal{E}$ Education 176: 104358.

Chawner, Brenda, and Gillian Oliver. 2013. A survey of New Zealand academic reference librarians: Current and future skills and competencies. Australian Academic \& Research Libraries 44: 29-39.

Cheng, Tien-Ming, Shu-Yun Chang, and Yin-Yun Chan. 2018. I know you are suffering from burnout: The moderated mediation effects of "leisure benefits" and "leisure coping" on the burnout model of flight attendants. Journal of Air Transport Management 71: 119-29. [CrossRef]

Choi, Hwansuk Chris, Shuyue Huang, Hyeyoon Choi, and Howook (Sean) Chang. 2020. The effect of flight attendants' physical attractiveness on satisfaction, positive emotion, perceived value, and behavioral intention. Journal of Hospitality and Tourism Management 44: 19-29. [CrossRef]

Cicek, Kadir, Emre Akyuz, and Metin Celik. 2019. Future Skills Requirements Analysis in Maritime Industry. Procedia Computer Science 158: 270-74. [CrossRef]

Condor. n.d. Flexibler Traumjob über den Wolken. Available online: https://condor-newsroom.condor.com/fileadmin/dam/user_ upload/Stellenbeschreibung_-_Flugbegleiter_in_Teilzeit_flexibel_unbefristet_hier_bewerben_.pdf (accessed on 29 April 2021).

Doerner, Karl, Gabriele Kotsis, and Christine Strauss. 2002. RosterBuilder: An Architecture for an Integrated Airline Rostering Framework. Department of Informatics INF, Copenhagen Business School. Working Paper/Institut for Informatik. Handelshøjskolen i København No. 2002-15. Available online: https://research-api.cbs.dk/ws/portalfiles/portal/58908851/6478.pdf (accessed on 8 December 2021).

Ehlers, Ulf-Daniel. 2020. Future Skills. Lernen der Zukunft-Hochschule der Zukunft. Wiesbaden: Springer. [CrossRef]

ESCO. 2020a. Get to Know ESCO. Last Update 27/08/2020. Available online: https://ec.europa.eu/esco/portal/home?resetLanguage= true\&newLanguage $=$ de (accessed on 28 September 2021).

ESCO. 2020b. Skills. Last Update 27/08/2020. Available online: https:/ /ec.europa.eu/esco/portal/skill? resetLanguage=true\& newLanguage $=$ en\&skillFilterIndex $=0$ (accessed on 28 September 2021).

European Commission. 2008. The European Qualifications Framework for Lifelong Learning (EQF). Luxembourg: Office for Official Publications of the European Communities, ISBN 978-92-79-08474-4. [CrossRef]

EW Discover. 2021. Cabin Crew Member (m/f/d). Available online: https://www.career.aero/discover/de/job/show/id/3457 (accessed on 21 April 2021).

Federal Ministry of Labour and Social Affairs of Germany. 2017. Re-Imagining Work: White Paper Work 4.0; Berlin: Federal Ministry of Labour and Social Affairs. Available online: https://www.bmas.de/SharedDocs/Downloads/EN/PDF-Publikationen/a883 -white-paper.pdf;jsessionid=CE83F4FFA31514A505653EFD4917166B.delivery1-replication?_blob=publicationFile\&v=1 (accessed on 28 September 2021).

Fidler, Devin. 2016. Future Skills. Update and Literature Review. Institute for the Future. Available online: https://www.iftf.org/ fileadmin/user_upload/downloads/wfi/ACTF_IFTF_FutureSkills-report.pdf (accessed on 28 September 2021).

Fischer, Stephan, André Häusling, Daniel Mühlbauer, Julian Huff, Julian Süß, Christian Vetter, Laura Bruckner, and Simon Werther. 2018. Implikationen von Arbeit 4.0 auf die Personalarbeit. In Arbeit 4.0 aktiv gestalten. Die Zukunft der Arbeit zwischen Agilität, People Analytics und Digitalisierung. Edited by Simon Werther and Laura Bruckner. Berlin: Springer, pp. 87-162.

Ford, Jane, Robert Henderson, and David O'Hare. 2013. Barriers to Intra-Aircraft Communication and Safety: The Perspective of the Flight Attendants. The International Journal of Aviation Psychology 23: 368-87. [CrossRef]

Gatta, Mary, Heather Boushey, and Eileen Appelbaum. 2009. High-Touch and Here-to-Stay: Future Skills Demands in US Low Wage Service Occupations. Sociology 43: 968-89. [CrossRef]

Gibbs, Latoya, Lisa Slevitch, and Isaac Washburn. 2017. Competency-Based Training in Aviation: The Impact on Flight Attendant Performance and Passenger Satisfaction. Journal of Aviation/Aerospace Education E Research 26: 55-80.

Grau-Gumbau, Rosa, Sonia Agut-Nietu, Susana Llorens-Gumbau, and Isabel Maria Martínez-Martínez. 2002. Managerial training needs: A study of Spanish tourism organizations. Tourism and Hospitality Research 3: 234-44. [CrossRef] 
Gray, Alex. 2016. The 10 Skills You Need to Thrive in the Fourth Industrial Revolution. Available online: https:/ / www.weforum.org/ agenda/2016/01/the-10-skills-you-need-to-thrive-in-the-fourth-industrial-revolution/ (accessed on 28 September 2021).

Grimm, Reinhard. 2009. Einfach komplex. Neue Herausforderungen im Projektmanagement. Wiesbaden: VS Verlag für Sozialwissenschaften.

Hammermann, Andrea, and Oliver Stettes. 2015. Fachkräftesicherung im Zeichen der Digitalisierung. Empirische Evidenz auf Basis des IW-Personalpanels 2014. Köln: Institut der deutschen Wirtschaft. Available online: https://www.bmwi.de/Redaktion/DE/ Downloads/F/fachkraeftesicherung-im-zeichen-der-digitalisierung.pdf?_blob=publicationFile\&v=4 (accessed on 28 September 2021).

Hammermann, Andrea, and Oliver Stettes. 2016. Qualifikationsbedarf und Qualifizierung. Anforderungen im Zeichen der Digitalisierung. IW Policy Paper 3/2016. Available online: https://www.econstor.eu/bitstream/10419/127450/1/847454444.pdf (accessed on 28 September 2021).

IATA (International Air Transport Association). 2021. Airline Business Confidence Index. October 2021 Survey. November 10. Available online: https:/ / www.iata.org/en/iata-repository/publications/economic-reports/business-confidence-survey---october--2021/ (accessed on 25 November 2021).

Jacobs, Joh. Christian, E. h. Henning Kagermann, Thomas Sattelberger, Thomas Lange, Philipp Depiereux, Christian van Alphen, Andreas Greve, Till Lohmann, Laura Bruckner, and Simon Werther. 2018. Aktuelle Studien zur Zukunft der Arbeit. In Arbeit 4.0 aktiv gestalten. Die Zukunft der Arbeit zwischen Agilität, People Analytics und Digitalisierung. Edited by Simon Werther and Laura Bruckner. Berlin: Springer, pp. 23-46.

Javed, Muhammad Sabih, Muhammad Razzaq Athar, Abdul Saboor, and Milena Ratajczak-Mrozek. 2019. Development of a twenty-first century skills scale for agri varsities. Cogent Business \& Management 6: 1. [CrossRef]

Ji, Ming, Bo Liu, Hongwei Li, Shiyun Yang, and Ying Li. 2019. The effects of safety attitude and safety climate on flight attendants' proactive personality with regard to safety behaviors. Journal of Air Transport Management 78: 80-86. [CrossRef]

Kao, Li-Hua, Margaret Stewart, and Kai-Hui Lee. 2009. Using structural equation modeling to predict cabin safety outcomes among Taiwanese airlines. Transportation Research Part E: Logistics and Transportation Review 45: 357-65. [CrossRef]

Karatepe, Osman M., and Aram Eslamlou. 2017. Outcomes of job crafting among flight attendants. Journal of Air Transport Management 62: 34-43. [CrossRef]

Karatepe, Osman M., and Sanaz Vatankhah. 2014. The effects of high-performance work practices and job embeddedness on flight attendants' performance outcomes. Journal of Air Transport Management 37: 27-35. [CrossRef]

Keller, Sarah. 2021. Statistiken zu den Auswirkungen des Coronavirus auf die Luftfahrtindustrie. Statista. Available online: https:/ / de.statista.com/themen/6257/coronavirus-und-luftfahrt/ (accessed on 28 September 2021).

Kim, Youngmi, and Hyejung Park. 2014. An Investigation of the Competencies Required of Airline Cabin Crew Members: The Case of a Korean Airline. Journal of Human Resources in Hospitality \& Tourism 13: 34-62.

Kirchherr, Julian, Julia Klier, Cornels Lehmann-Brauns, and Mathias Winde. 2018. Future Skills. Welche Kompetenzen in Deutschland fehlen. Stifterverband für die Deutsche Wissenschaft (Ed). Available online: https://www.future-skills.net/analysen/futureskills-welche-kompetenzen-in-deutschland-fehlen (accessed on 28 September 2021).

Kirchherr, Julian, Julia Klier, Volker Meyer-Guckel, and Mathias Winde. 2020. Future Skills Analysen. Die Zukunft der Qualifizierung in Unternehmen nach Corona. Stifterverband für die Deutsche Wissenschaft (Ed.). Available online: https:/ /www.future-skills. net/analysen/die-zukunft-der-qualifizierung-in-unternehmen-nach-corona (accessed on 28 September 2021).

Koch, Jonas Maximilian. 2017. Kompetenzen des Industriearbeiters 4.0. Fachhochschule Südwestfalen, Hochschulschriften, Standort Meschede 2/2017. Available online: https:/ / www4.fh-swf.de/media/downloads/meschedestandort/hochschulschriften/pdfs_ 2/02_2017/MHS_2.pdf (accessed on 3 December 2021).

Kockelke, Kathrin. 2008. Der Einfluss der Bordleistungen auf die Kundenzufriedenheit bei Flugreisen unter besonderer Berücksichtigung des Flugbegleiters. Ph.D. thesis, Universität Mannheim, Mannheim, Germany. Available online: https://madoc.bib.unimannheim.de/1949/1/Dissertation_Kockelke.pdf?rs=true\&\#38;wid= (accessed on 6 December 2021).

Koenen, Jens. 2020. Sparprogramme bei den Airlines. Wie Andere Fluggesellschaften mit der Krise umgehen. Handelsblatt. September 8. Available online: https:/ / www.handelsblatt.com/unternehmen/handel-konsumgueter/sparprogramme-bei-den-airlines-wieandere-fluggesellschaften-mit-der-krise-umgehen/26164558.html?ticket=ST-7299064-O0kEwPVPs91e9G1cSG0m-ap3 (accessed on 28 September 2021).

Kusumo, Laksmi. 2016. Problem-based learning technique in developing the initial flight attendant students' speaking skills. Proceedings Universitas Pamulang 1: 146-56.

Latson, Jennifer. 2015. Hired for Their Looks, Promoted for Their Heroism: The First Flight Attendants. Time. May 15. Available online: https:/ / time.com/3847732/first-stewardess-ellen-church/ (accessed on 28 September 2021).

Lee, Chongho, Myungsook An, and Yonghwi Noh. 2012. The Social Dimension of Service Workers' Job Satisfaction: The Perspective of Flight Attendants. Journal of Service Science and Management 5: 160-70. [CrossRef]

Limprasert, Sirima, and Krit Witthawassamrankul. 2016. English communication problems between passengers and flight attendants: A review. Paper presented at the RTUNC National Conference, Ubon Ratchathani, Thailand, July 29; Available online: https://www.researchgate.net/profile/Krit-Witthawassamrankul/publication/318039199_English_ Communication_Problems_between_Passengers_and_Flight_Attendants_A_Review/links/595624d5a6fdcc2569d9b8ab / English-Communication-Problems-between-Passengers-and-Flight-Attendants-A-Review.pdf (accessed on 8 December 2021). 
Lu, Jin-Long, and Feng-I Ling. 2008. Cross-cultural perspectives regarding service quality and satisfaction in Chinese cross-strait airlines. Journal of Air Transport Management 14: 16-19. [CrossRef]

Lufthansa. 2020. Lufthansa Flugbegleiter-Bewerbung: Voraussetzungen (Promotional Video). Available online: https:/ / www.youtube. $\mathrm{com} /$ watch? $\mathrm{v}=\mathrm{OAX} 46 \mathrm{peEmjc}$ (accessed on 6 December 2021).

Lüneburg, Anke. 2020. Erfolgreich sein als Führungskraft in der Arbeitswelt 4.0. Begeisterung wecken mit Zukunftskompetenzen und Coaching-Tools. Wiesbaden: Springer.

OECD. 2019. OECD Future of education and skills 2030, OECD Learning Compass 2030. Available online: https://www.oecd.org/ education/2030-project/contact/OECD_Learning_Compass_2030_Concept_Note_Series.pdf (accessed on 17 September 2020).

Park, Hyun-Seo, and Hye-Yoon Park. 2019. The Effect of Efficiency Evaluation on the Organizational Effectiveness of the Cabin Crew's Competency-Focusing on the Job Satisfaction of the Personal Capacity of Airline Cabin Crews. Journal of Distribution Science 17: 5-13. [CrossRef]

Partnership for 21st Century Learning (P21). 2019. Framework for 21st Century Learning Definitions. Available online: https: / / static.battelleforkids.org/documents/p21/P21_Framework_DefinitionsBFK.pdf (accessed on 18 March 2021).

Robertson-von Trotha, Caroline Y., Jens Görisch, and Iris Helene Koban. 2009. Projekte zu Schlüsselqualifikationen an Technischen Universitäten. Konzeptionelle Überlegungen, empirische Erhebungen und interuniversitärer Austausch. In Schlüsselqualifikationen für Studium, Beruf und Gesellschaft. Technische Universitäten im Kontext der Kompetenzdiskussion. Edited by Caroline Y. Robertson-von Trotha. Karlsruhe: Universitätsverlag Karlsruhe, pp. 135-68.

Rump, Jutta, and Silke Eilers. 2017. Auf dem Weg zur Arbeit 4.0. Innovationen in HR. Berlin: Springer.

Sauter, Roman, Werner Sauter, and Roland Wolfig. 2018. Agile Werte- und Kompetenzentwicklung. Wege in eine neue Arbeitswelt. Berlin: Springer.

Scheunemann, York. 2018. Selbst. Achtsam. Managen. In Arbeitswelt der Zukunft. Trends-Arbeitsraum-Menschen -Kompetenzen. Edited by Harald R. Fortmann and Barbara Kolocek. Wiesbaden: Springer, pp. 243-81.

Schönfelder, Christoph. 2018. Muße-Garant für unternehmerischen Erfolg. Ihr Potenzial für Führung und die Arbeitswelt 4.0. Wiesbaden: Springer.

Schubert, Sascha. 2018. Grußwort Bundesverband Deutsche Startups e.V. In Arbeit 4.0 aktiv gestalten. Die Zukunft der Arbeit zwischen Agilität, People Analytics und Digitalisierung. Edited by Simon Werther and Laura Bruckner. Berlin: Springer, pp. V-VI.

Seitz, Jelka, and Jürgen Seitz. 2018. Digitale Kompetenzen: New Work = New Human? In Arbeitswelt der Zukunft. Trends-ArbeitsraumMenschen-Kompetenzen. Edited by Harald R. Fortmann and Barbara Kolocek. Wiesbaden: Springer, pp. $355-82$.

Statistisches Bundesamt. 2021. Verkehr. Luftverkehr auf Hauptverkehrsflughäfen. Fachserie 8 Reihe 6.1 2020. Available online: https:/ / www.destatis.de/DE/Themen/Branchen-Unternehmen/Transport-Verkehr/Personenverkehr/Publikationen/ Downloads-Luftverkehr/luftverkehr-ausgewaehlte-flugplaetze-2080610207004.pdf;jsessionid=5CE3DC4DAAA49E069F5C8 0A92F12F4A0.live712?_blob=publicationFile (accessed on 2 June 2021).

Tang, Au Due, Man-Ling Chang, Tsu-Hui Wang, and Cheng-Hao Lai. 2020. How to create genuine happiness for flight attendants: Effects of internal marketing and work-family interface. Journal of Air Transport Management 87: 101860. [CrossRef]

Tyler, Melissa, and Pamela Abbott. 1998. Chocs Away: Weight Watching in the Contemporary Airline Industry. Sociology 32: 433-50. [CrossRef]

Vatankhah, Sanaz. 2021. Dose safety motivation mediate the effect of psychological contract of safety on flight attendants' safety performance outcomes?: A social exchange perspective. Journal of Air Transport Management 90: 101945. [CrossRef]

Vieira, Ana Maria, and Isabel Cristina dos Santos. 2010. Communication skills: A mandatory competence for ground and airplane crew to reduce tension in extreme situations. Journal of Aerospace Technology and Management 2: 361-70. [CrossRef]

Wen, Xin, Xuting Sun, Yige Sun, and Xiaohang Yue. 2021. Airline crew scheduling: Models and algorithms. Transportation Research Part E: Logistics and Transportation Review 149: 102304. [CrossRef]

World Economic Forum. 2020. The Future of Jobs Report 2020. Cologny/Geneva. Available online: http:/ /www3.weforum.org/docs/ WEF_Future_of_Jobs_2020.pdf (accessed on 1 March 2021). 